\title{
Characterization and Antimicrobial-Resistance Profile of Escherichia coli 0157 and 0157: H7 Isolated from Modified Atmosphere Packaged Meat Samples
}

\author{
Özgür Çadırcı*, Ali Gücükoğlu, Göknur Terzi Gülel, Tolga Uyanık \\ Abdulaziz Abdulahi, Mustafa Alişarlı
}

Department of Food Hygiene and Technology, Faculty of Veterinary Medicine, University of Ondokuz Mayls, 55200 Samsun, Turkey

\section{A R T I C LE IN F O}

\section{Research Article}

Received 15 March 2017

Accepted 27 August 2017

\section{Keywords.}

MAP

Minced and cubed meat

Escherichia coli O157: H7

mPCR

Antimicrobial resistance

*Corresponding Author:

E-mail: o.cadirci@omu.edu.tr
A B S T R A C T

$\overline{\text { Shiga-like toxin producing Escherichia coli is still an important public issue which causes }}$ extremely dangerous health problems. This study was planned in order to examine the inhibitory effect of Modified Atmosphere Packaging application on E. coli $\mathrm{O} 157$ and O157: H7. The purposes of the present study were to detect E. coli O157 and O157: H7 strains from ground and cubed beef. A total of 100 MAP cattle meat products (50 minced meat, 50 meat cubes) were collected from the markets and butchers in Samsun province between May and October 2013. According to results, 1(1/50-2\%) E. coli O157 and 1(1/50-2\%) E. coli O157: $\mathrm{H} 7$ strains isolated from 50 ground beef samples, while 1 (1/502\%) E. coli $\mathrm{O} 157$ strain was identified from 50 cubed beef samples. It was determined that $E$. coli $\mathrm{O} 157$ isolate obtained from the MAP ground beef carried $s t x_{1}$, st $x_{2}$ genes; $E$. coli $\mathrm{O} 157$ : $\mathrm{H} 7$ isolate carried $s t x_{1}$, stx 2 , eaeA and hylA genes while E. coli $\mathrm{O} 157$ isolate obtained from the MAP cubed meat only carried the stx $_{2}$ gene. In antibiogram test, both E. coli $\mathrm{O} 157$ isolates were resistant to streptomycin and one E. coli $\mathrm{O} 157: \mathrm{H} 7$ isolate was resistant to streptomycin, cephalothin and tetracycline. As a consequence; in order to protect public health, products should be kept in proper hygienic and technical conditions during sale and storage and use of uncontrolled antibiotics should be avoided.

Türk Tarım - G1da Bilim ve Teknoloji Dergisi, 5(10): 1142-1147, 2017

\section{Modifiye Atmosfer Paketli Et Örneklerinden İzole Edilen Escherichia coli O157 ve O157: H7'nin Karakterizasyonu ve Antibiyotik Direnç Profili}

\section{A K A L E B İ L G İ S İ}

\section{AraştırmaMmakalesi}

Geliş 15 Mart 2017

Kabul 27 Ağustos 2017

\section{Anahtar Kelimeler:}

MAP

Paketli sığır kıyma ve kuşbaşı

Escherichia coli O157: H7

mPCR

Antibiyotik dirençlilik

"Sorumlu Yazar:

E-mail: o.cadirci@omu.edu.tr

\section{Ö Z E T}

Bu çalışmada 2013 yılında Mayıs ve Ekim ayları arasında Samsun ilinde satışa sunulan Modifiye Atmosfer Paketli (MAP) sığır kıyma ve kuşbaşı örneklerinde Escherichia coli O157 ve O157: H7'nin klasik kültür tekniği kullanılarak belirlenmesi, PCR ile doğrulanması, genomik karakterizasyonu ve fenotipik antibiyotik dirençlilik profillerinin ortaya konulması amaçlanmıştır. Araştırmada toplam 100 (50 sığır kıyma-50 sı̆̆ır kuşbaşı) adet MAP sığır et ürünü materyal olarak kullanılmıştır. Analiz edilen 50 MAP sığır kıyma örneğinin 1'inin (1/50-\%2) E. coli O157, diğerinin (1/50-\%2) E. coli O157: H7 ile, 50 adet MAP sığır kuşbaş1 örneğinin 1'inin (1/50-\%2) ise E. coli O157 ile kontamine olduğu belirlenmiştir. Yapılan genotiplendirme sonucunda MAP sığır kıyma örneklerinden elde edilen $E$. coli O157 izolatının stxl, stx2, E. coli O157: H7 izolatının ise $s t x 1$, stx2, eaeA ve $h l y A$ gen bölgelerini taşıdığı, MAP sığır kuşbaş1 örneklerinden elde edilen E. coli $\mathrm{O} 157$ izolatının ise sadece stx2 gen bölgesini taşıdığı belirlenmiştir. Fenotipik antibiyotik profil analizinde E. coli O157 izolatlarının her ikisinin yalnızca streptomisine karşı dirençli olduğu bununla beraber E. coli O157: H7 izolatının ise streptomisin, sefalothin ve tetrasiklin antibiyotiklerine karşı dirençli olduğu saptanmıştır. Sonuç olarak halk sağlığının korunması amacıyla ürünlerin uygun teknik ve hijyenik şartlarda satışa sunulması ve muhafaza edilmesine dikkat edilmesi, ayrıca izolatların antibiyotiklere direnç göstermesi nedeniyle kontrolsüz antibiyotik kullanımının önlenmesi önerilmektedir. 


\section{Introduction}

Escherichia coli (STEC) that produces Shiga toxin is still on the agenda as an important public health issue that results from zoonosis. Asymptomatic cattles are considered as primary source for E. coli O157: $\mathrm{H} 7$ infections. In previous surveys carried out, it is known that the dominant prevalence in cattle is between $1 \%$ and 71\% (Meng et al. 1995; Hussein and Sakuma 2005). The terminal recto-anal junction (RAJ) becomes colonized in carrier animals, and it is found at a level of 10-100 CFU/g in faeces. It is known that in most cases the infection is formed as a result of consuming undercooked meat contaminated with cattle faeces. The effects of $E$. coli serotype with STEC character lead to bloody diarrhea among non-complicated diarrheal cases in people (Hemorrhagic Colitis) and haemolytic uremic syndrome (HUS) that reaches a point that threatens human life in advanced cases. Five major STEC serotypes have been determined so far, and these are known as O26: H11, O103: H2, O111: H8, O145: H28, O157: H7. It is reported that major virulence factors of $E$. coli $\mathrm{O} 157$ : $\mathrm{H} 7$ are the production of $s t x 1, s t x 2$ or their variants that are coded by lysogenic and lambdoid bacteriophages. Another important virulence factor is eae gene that localized in the chromosome and coding the intimine $(E$. coli bonding and adherence protein). These proteins ensure the adherence of the factor on the surface of intestinal epithelium (Eklund 2005). At the same time, it is reported in the studies carried out in recent years, $E$. coli O157: H7 develops multiple resistances to several antibiotics and this resistance mechanism developed contributes to virulence of the bacteria. Multiple antibiotic resistance mechanism of the agent is generally explained by mutation, selective repression and genetic transformation (Schroeder et al. 2002). The modified atmosphere packaging is a food preservation technique widely used in many food products to increase the shelf life. With the MAP technology, it is aimed to reduce the speed of respiration, slow down oxidative and enzymatic deteriorations, delay microbial deterioration as much as possible by inhibiting or stopping microbial reproduction, and thus, increase the shelf life of products. Oxygen $\left(\mathrm{O}_{2}\right)$, carbon dioxide $\left(\mathrm{CO}_{2}\right)$ and nitrogen $\left(\mathrm{N}_{2}\right)$ are widely used gas components in order to change the atmosphere composition in the package (Cooksey 2014).

In this research, it was objectived to i) determine the presence of E. coli $\mathrm{O} 157$ and $\mathrm{O} 157: \mathrm{H} 7$ using the classical culture technique, ii) confirm the isolates and associated genes by PCR, and iii) reveal the phenotypic antibiotic resistance profiles of the isolates obtained from Modified Atmosphere Packaged (MAP) beef minced meat and meat cube samples.

\section{Material and Methods}

A total of 100 MAP cattle meat products (50 minced meats, 50 meat cubes) were collected from the markets and butchers in Samsun province between May and October 2013. All samples were transported to the laboratory in the shortest time possible under the cold chain and analyzed immediately. The samples were selected from different parties, and the packages were at least $500 \mathrm{~g}$.
Isolation and Identification of E. coli $O 157$ and E. coli O157: $H 7$

In the enrichment process, Modified Tryptone Soy Broth (mTSB- Merck 1.09205) containing $225 \mathrm{ml}$ of novobiocin was added to $25 \mathrm{~g}$ of the sample taken to sterile bags and incubated at $41.5^{\circ} \mathrm{C}$ for $18-24 \mathrm{~h}$. A loop of suspension was taken to Tellurite $(2.5 \mathrm{mg} / \mathrm{l})$ Cefixime (0.05 mg/l)-Sorbitol Mac Conkey (CT-SMAC) agar (Oxoid-CM 813, Supl. SR 172 E) and the plates were incubated at $37^{\circ} \mathrm{C}$ for $24 \mathrm{~h}$. Following the incubation, 5 suspected colonies that did not fermentate sorbitol reproduced in the plates were chosen, subcultured in Yeast Extract-Trypticase Soy Agar (TSA-YE) (Oxoid$\mathrm{CM} 131-\mathrm{L} 21$ ), and the plates were incubated at $37^{\circ} \mathrm{C}$ for 24-48 h. The suspected isolates were streaked onto Sorbitol Mac Conkey Agar (SMAC-MUG Supl. OxoidBR 071 E) containing 4-methylumbelliferly-B-DGlucuronide (MUG) by the drawing method the plates were incubated at $37^{\circ} \mathrm{C}$ for $24 \mathrm{~h}$. In addition, indole and motility tests were performed. The colonies that did not represent fluorescent light under UV light (at $366 \mathrm{~nm}$ wavelength) were assessed as MUG-negative. Isolates were then inoculated on Purple Broth Base (Difco-022701-6) containing cellobiose and incubated at $37^{\circ} \mathrm{C}$ for 24 h. Consequently; non-sorbitol fermenting, indole positive, motile, MUG negative, non-cellobiose fermenting colonies were selected and agglutination test was performed to these colonies with 0157 antiserum (DR0620M; Oxoid, UK). Agglutination positive isolates were considered as E. coli O157. Afterwards, E. coli $\mathrm{O} 157$ isolates were tested with $\mathrm{H} 7$ antiserum and agglutination positive strains were considered as $E$. coli O157: H7 (Cagney et al. 2004; Dontorou et al. 2004).

Confirmation of Isolates with Multiplex PCR and Determination of stx 1 , stx2, eaeA and hlyA Genes

Confirmation of E. coli $\mathrm{O} 157$ and E. coli O157: $\mathrm{H} 7$ isolates were performed using mPCR. The presence of stx 1 , stx 2 , eaeA and $h l y A$ genes was carried out according to the procedure described by Maurer et al. (1999) and Fratamico et al. (2000). List of primers used was shown in Table 1. E. coli O157: H7 ATCC 43895 and E. coli O157: H7 ATCC 35150 were used as reference strains.

\section{DNA Extraction}

The genomic DNA extraction of isolates was performed with boiling method. Briefly, the isolates were incubated at $37^{\circ} \mathrm{C}$ for $24 \mathrm{~h}$ in Brain Heart Infusion Broth (BHI-Oxoid CM 0225), then $1 \mathrm{ml}$ suspension was transferred to sterile eppendorf tubes and centrifuged for 5 min at $10,000 \times \mathrm{g}$ (Hettich Universal 320R, Germany). Afterwards, the supernatant was discarded and the pellet was resuspended in $500 \mu \mathrm{L}$ of PBS and kept in a water bath at $95^{\circ} \mathrm{C}$ for $10 \mathrm{~min}$. Then centrifuged again for $5 \mathrm{~min}$ at $10,000 \times \mathrm{g}$. The extracted DNA was stored at $-20^{\circ} \mathrm{C}$ until analysis.

\section{mPCR and Electrophrosesis}

PCR mixture was prepared in a total volume of $50 \mu \mathrm{L}$ containing 1X PCR Buffer (Sigma P2317), $1.5 \mathrm{mM}$ $\mathrm{MgCl}_{2}$ (Sigma M8787), $0.1 \mathrm{mM}$ dNTP (Sigma DNTP100A), 0.5 U Taq-Polymerase (Sigma D4545), 1 $\mu \mathrm{M}$ of each primer and $5 \mu \mathrm{L}$ of target DNA. 
Table 1 Characteristics primers used for detection of $E$. coli $\mathrm{O} 157: \mathrm{H} 7$ and virulence genes

\begin{tabular}{|c|c|c|c|}
\hline Primer & Sequence (5'- 3') & Product size (bp) & Reference \\
\hline$r f b 0157 \mathrm{~F} r f b 0157 \mathrm{R}$ & $\begin{array}{l}\text { CGTGATGATGTTGAGTTG } \\
\text { AGATTGGTTGGCATTACTG }\end{array}$ & 420 & (9) \\
\hline fliCh7 F fliCh7 R & $\begin{array}{l}\text { GCGCTGTCGAGTTCTATCGAGC } \\
\text { CAACGGTGACTTTATCGCCATTCC }\end{array}$ & 625 & (9) \\
\hline stxl $\mathrm{F} \quad$ stxl $\mathrm{R}$ & $\begin{array}{l}\text { TGTAACTGGAAAGGTGGAGTATACA } \\
\text { GCTATTCTGAGTCAACGAAAAATAAC }\end{array}$ & 210 & (9) \\
\hline$s t x 2 \mathrm{~F} \quad s t x 2 \mathrm{R}$ & $\begin{array}{l}\text { GTTTTTCTTCGGTATCCTATTCC } \\
\text { GATGCATCTCTGGTCATTGTATTAC }\end{array}$ & 484 & (9) \\
\hline eaeA F eaeA $\mathrm{R}$ & $\begin{array}{l}\text { ATTACCATCCACACAGACGGT } \\
\text { ACAGCGTGGTTGGATCAACCT }\end{array}$ & 397 & (9) \\
\hline$h l y A \mathrm{~F}$ hlyA R & $\begin{array}{l}\text { ACGATGTGGTTTATTCTGGA } \\
\text { CTTCACGTCACCATACATAT }\end{array}$ & 166 & (9) \\
\hline
\end{tabular}

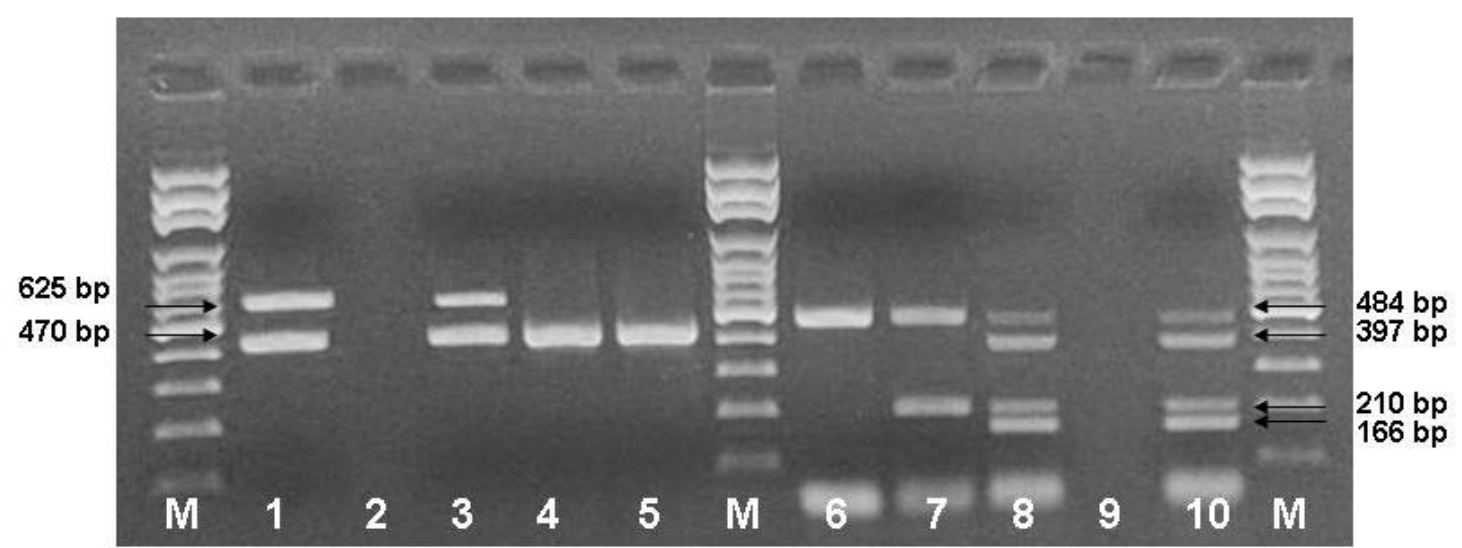

Figure 1 Electrophorese Image of $r f b o 157$, flich7, stx1, stx2, eaea and hlya Genes of Isolates by Multiplex PCR. [M: 100 bp DNA marker, lane 1: Positive control for $r f b O 157$ and fliCh7 genes (E. coli O157:H7 ATCC 43895), lane 2: Negative control, lane 3: $r f b O 157$ and $f l i C h 7$ positive isolate, lane 4-5: rfbO157 positive isolates lane 6: stx2 gene positive isolate, lane 7: stxl, stx2 gene positive isolates, lane 8: stx2, eaeA, stxl and $h l y A$ genes positive isolates, lane 9: Negative control, lane 10: Positive control for stx2, eaeA, stxl and $h l y A$ genes (E. coli O157:H7 ATCC 35150)]

The amplification of the $r f b O 157, f l i C h 7$, stxl, stx2, eaeA and hlyA genes was performed in Thermal Cycler (Bio-Rad MJ mini Gradient CA-USA), as follows: initial denaturation at $94^{\circ} \mathrm{C}$ for $2 \mathrm{~min}$, followed by 35 cycles at $94^{\circ} \mathrm{C}$ for 20 seconds, annealing at $54^{\circ} \mathrm{C}$ for $1 \mathrm{~min}$, extension at $72^{\circ} \mathrm{C}$ for $1 \mathrm{~min}$, followed by a final extension at $72^{\circ} \mathrm{C}$ for $10 \mathrm{~min}$ (Fratamico et al. 2000). The acquired amplicons were run on 2\% agarose gel (Sigma A9539; Tris-Borate-EDTA, Sigma T4415) at $90 \mathrm{~V}$ for $90 \mathrm{~min}$ (BioRad Power Pac-Basic, Singapore) containing ethidium bromide $(5 \mu \mathrm{g} / \mathrm{ml}) .100$ bp DNA ladder was used as DNA size marker in in the process. The PCR products were visualized under UV illumination for rfbO157, fliCh7, stxl, stx2, eaeA and hylA genes at 420 bp, 625 bp, 210 bp, 484 bp, 397 and 166 bp respectively (Wise-UV-Wuv-L50, Grafstal, Germany) (Figure 1).

\section{Antimicrobial Susceptibility Test}

Antimicrobial susceptibility testing was performed using the disc diffusion method on Mueller-Hinton agar (Oxoid, UK). For this purpose, ten antibiotic disks were chosen as follows: Sulphamethoxazole-Trimethoprim (Oxoid-CT 0052B, $25 \mu \mathrm{g}$ ), Ampicillin (Oxoid-CT 0003B, $10 \mu \mathrm{g}$ ), Amoxicillin (Oxoid-CT 0223B, $30 \mu \mathrm{g}$ ), Cephalothin (Oxoid CT0010B, $30 \mu \mathrm{g}$ ), Chloramphenicol (Oxoid-CT0013B, $30 \mu \mathrm{g}$ ), Tetracycline (Oxoid CT0054B, $30 \mu \mathrm{g}$ ), Ofloxacin (Oxoid-CT0446B, $10 \mu \mathrm{g}$ ), Ciprofloxacin (Oxoid-CT1615B, $10 \mu \mathrm{g}$ ), Streptomycin (Oxoid-CT0047B, $10 \mu \mathrm{g}$ ), Gentamycin (Oxoid-CT0024B,
$10 \mu \mathrm{g})$. Briefly, $24 \mathrm{~h}$ fresh colonies were grown at $35{ }^{\circ} \mathrm{C}$ for $24 \mathrm{~h}$ in tryptic soy broth (Merck 1.05459) with yeast extract (Oxoid LP0021). After incubation, the turbidity of colonies was adjusted to $0.5 \mathrm{McFarland}\left(10^{8} \mathrm{CFU} / \mathrm{ml}\right)$ using a McFarland densitometry (Biosan, DEN-1, Latvia). $1 \mathrm{ml}$ of the bacteria suspension was spread onto MHA (Oxoid CM 337) using a sterile swab and plates were dried for 10-15 min at room. Then plates were incubated at $35^{\circ} \mathrm{C}$ for $18-24 \mathrm{~h}$ by placing antibiotic discs. At the end of the incubation, the diameters of the inhibition zones around antibiotic discs were measured, and the isolates were classified as sensitive, intermediate or resistant (Wayne 2007).

\section{Results and Discussion}

It is determined that 1 of $50(1 / 50-2 \%)$ MAP beef minced meat samples analyzed is contaminated with $E$. coli $\mathrm{O} 157$, the other $(1 / 50-2 \%)$ is contaminated with $E$. coli O157: H7, and 1 of $50(1 / 50-2 \%)$ MAP beef meat cube samples $(1 / 50-2 \%)$ is contaminated with E. coli O157 (Table 2).

All around the world, the studies carried out in order to show the importance of contamination frequency, the risk level incurred and importance in the sense of public health in terms of E. coli O157: H7 serotype are similar to the findings of this research. Doyle and Schoeni (1987) isolated the agent in 6 of 164 beef meat (3.7\%), 4 of 264 pork (1.5\%), 4 of 263 poultry (1.5\%), and 4 of 205 lamb 
meat (2.0\%). Willshaw et al. (1994) detected E. coli 0157 not forming verotoxin in $5(1.6 \%)$ of 134 minced meat, 52 sausage and 124 hamburger samples in the UK. AbdulRaouf et al. (1996) reported that they isolated E. coli O157:H7 in $3(6 \%)$ of 50 beef minced meat samples. In Switzerland, Fantelli and Stephan (2001) reported 2.3\% prevalance of $E$. coli O157: $\mathrm{H} 7$ in 211 ground beef samples. Guyon et al. (2001) reported that they isolated only one $E$. coli $\mathrm{O} 157$ : $\mathrm{H} 7$ only from 225 beef samples. In Turkey, the prevalence of the agent was investigated in various studies. Temelli et al. (2012) detected the prevalence of the agent $5.55 \%$ from 106 meat samples. In a study they conducted on 100 hamburger and İnegöl meatballs, Sarımehmetoğlu et al. (1998) reported that 5\% of İnegöl meatballs and $2 \%$ of hamburgers were contaminated with $E$. coli $\mathrm{O} 157$, and all of the isolates were of verotoxigenic character. Alişarlı and Akman (2004), detected E. coli $\mathrm{O} 157$ in $4.6 \%$ (7/150) of 150 minced beef meat, and in $2 \%(3 / 150)$ of 150 minced mutton meat samples. In the study conducted by Keleş et al. (2006), researchers detected the pathogen in 1 of minced meat samples, 3 of cooled İnegöl meatballs, 1 of frozen İnegöl meatballs, and 3 of frozen hamburger meatballs examined. In the study conducted by Cadirci et al. (2010), researchers analysed 100 ground beef and 100 raw meatball samples by immunomagnetic separation and PCR methods and detected 1 E. coli $\mathrm{O} 157$ from ground beef, and 4 E. coli 0157 from raw meatballs. Researchers also indicated that these strains were negative for $\mathrm{H} 7$.

As a result of the PCR analysis conducted, it was determined that the E. coli $\mathrm{O} 157$ isolate obtained from MAP beef minced meat samples contained the gene zones stx 1, stx2; E. coli O157: $\mathrm{H} 7$ isolate contained the gene zones stxl, stx2, eaeA and hlyA; and E. coli $\mathrm{O} 157$ isolate obtained from MAP beef meat cube samples contained only the stx 2 gene region (Table 2 ). The pathogenesis of the agent depends on several virulence factors such as stxl and stx2, intimin and enterohemolysin. The disease caused by STEC is an important public health issue. It is reported that a great majority of the strains of these microorganisms contain stx 2 , some of them contain stx 1 and st 2 , and just a very small portion contain only the stxl gene (Law 2000). In line with the literature, it has been determined in this study that the most frequently detected toxin gene is stx2. Cagney et al. (2004) examined 1533 beef minced meat and burger samples and it was determined that 43 isolates they obtained had eaeA, hlyA and fliCh7 genes, and 41 isolates had $s t x_{1}$ and $s t x_{2}$ genes. The presence of these two virulence factors (eaeA and hlyA) bears a resemblance to this study.

Varela-Hernandez et al. (2007), collected 27 E. coli O157: $\mathrm{H} 7(\mathrm{n}=11)$ and E. coli $\mathrm{O} 157(\mathrm{n}=16)$ in total from 258 carcasses and tested them in terms of virulence factors using the multiplex PCR process. The st 2 , eaeA and hylA genes were detected only in 1 E. coli O157: H7 isolate. In the study, they carried out for the purpose of determining the presence of $E$. coli O157: $\mathrm{H} 7$ and virulence genes, Ertaş et al. (2013), examined a total of 500 samples consisting of meat cubes, minced meat, hamburgers, raw cow milk and cheese made from raw cow milk; and the presence of E. coli O157: H7 was determined in $5(1 \%)$ samples in total, 2 samples of meat cubes, 1 sample of minced meat and 2 samples of raw milk, among 500 samples. They reported that 3 of these isolates $(3 / 5-60 \%)$ were positive in terms of the stx 1 , stx 2 and $h l y A$ genes. However, 2 isolates isolated from raw milk products carried the stxl,eaeA and $h l y A$ genes.

Antimicrobial susceptibility testing results showed that both of $E$. coli $\mathrm{O} 157$ isolates are resistant only to streptomycin while $E$. coli $\mathrm{O} 157$ : $\mathrm{H} 7$ isolate is resistant to streptomycin, cephalothin and tetracycline antibiotics (Table 3). Multiple antimicrobial resistance is a widespread case among E. coli O157: H7 strains isolated from different sources. Schroeder et al. (2002), have detected that $17 \%$ of E. coli $\mathrm{O} 157$ isolates in the US are resistant to one antimicrobial, $7.5 \%$ are resistant to two antimicrobials, $8 \%$ are resistant to three antimicrobials, $5 \%$ are resistant to four, $2 \%$ are resistant to five, and $0.1 \%$ is resistant to six different antimicrobials. Similarly, Zhao et al. (2001), have determined that 4 of 29 E. coli O157: $\mathrm{H} 7$ isolates obtained from human, animal and food resources in the US show resistance to 5 different antibiotics, these being tetracycline, ampicillin, streptomycin, kanamycin, and sulfamethoxazole. They reported that 2 of these 4 isolates were of human origin while the other 2 were of minced meat origin.

Table 2 Prevalence of stx1, stx2, eaeA and hlyA genes in E. coli $\mathrm{O} 157$ and $\mathrm{H} 7$ isolates from MAP minced and cubed meat samples

\begin{tabular}{|c|c|c|c|c|c|c|c|c|}
\hline \multirow{2}{*}{ Samples } & \multirow{2}{*}{$\begin{array}{c}\text { Number of } E \text {. coli } \\
\text { O157 and H7 positive } \\
\text { samples }(\%)\end{array}$} & \multicolumn{3}{|c|}{$\begin{array}{c}\text { Number of } E \text {. coli } \mathrm{O} 157 \text { and } \mathrm{H} 7 \text { positive } \\
\text { isolates ( } r f b O 157 \text { and } f l i C h 7 \text { genes) }\end{array}$} & \multicolumn{4}{|c|}{ Virulence genes } \\
\hline & & $\begin{array}{l}\text { Isolate } \\
\text { code }\end{array}$ & $\begin{array}{l}\text { E. coli } \mathrm{O} 157 \\
(r f b O 157)\end{array}$ & $\begin{array}{l}\text { E. coli } \mathrm{O} 157: \mathrm{H7} \\
(\text { fliCh7 })\end{array}$ & stxl & stx 2 & $e a e A$ & hlyA \\
\hline \multirow{2}{*}{ Minced Meat (n:50) } & \multirow{2}{*}{$2(4 \%)$} & $33-1$ & + & - & + & + & - & - \\
\hline & & $72-1$ & + & + & + & + & + & + \\
\hline Cubed Meat (n:50) & $1(2 \%)$ & $60-1$ & + & - & - & + & - & - \\
\hline
\end{tabular}

Table 3 Antibiotic resistance profiles of E. coli $\mathrm{O} 157$ and $\mathrm{H} 7$ from MAP minced and cubed meat samples.

\begin{tabular}{|c|c|c|c|c|c|c|c|c|c|c|c|c|c|c|c|c|c|c|c|c|c|c|c|c|c|c|c|c|c|c|c|c|}
\hline \multirow{3}{*}{$\mathrm{C}$} & \multicolumn{32}{|c|}{ Results of Disc Diffusion Test } \\
\hline & \multirow{2}{*}{$1 \mathrm{E}$} & \multirow{2}{*}{$2 \mathrm{E}$} & \multicolumn{3}{|c|}{ ST } & \multicolumn{3}{|c|}{ AM10 } & \multicolumn{3}{|c|}{ AM30 } & \multicolumn{3}{|c|}{ CE30 } & \multicolumn{3}{|c|}{$\mathrm{CH} 30$} & \multicolumn{3}{|c|}{ TE30 } & \multicolumn{3}{|c|}{ OX10 } & \multicolumn{3}{|c|}{ CI10 } & \multicolumn{3}{|c|}{ ST10 } & \multicolumn{3}{|c|}{ GE10 } \\
\hline & & & $\mathrm{R}$ & $\mathrm{I}$ & $\mathrm{S}$ & $\mathrm{R}$ & $\mathrm{I}$ & $\mathrm{S}$ & $\mathrm{R}$ & $\mathrm{I}$ & $\mathrm{S}$ & $\mathrm{R}$ & I & $S$ & $\mathrm{R}$ & I & $\mathrm{S}$ & $\mathrm{R}$ & I & $\mathrm{S}$ & $\mathrm{R}$ & $\mathrm{I}$ & $\mathrm{S}$ & $\mathrm{R}$ & $\mathrm{I}$ & $\mathrm{S}$ & $\mathrm{R}$ & I & $\mathrm{S}$ & $\mathrm{R}$ & I & $\mathrm{S}$ \\
\hline $33-1$ & + & - & - & - & + & - & - & + & - & - & + & - & - & + & - & - & + & - & - & - & - & - & + & - & - & + & + & - & - & - & - & + \\
\hline $72-1$ & + & + & - & - & + & - & - & + & - & - & + & + & - & - & - & - & + & + & - & + & - & - & + & - & - & + & + & - & - & - & - & + \\
\hline $60-1$ & + & - & - & - & + & - & - & + & - & - & + & - & - & + & - & - & + & - & - & + & - & - & + & - & - & + & + & - & - & - & - & + \\
\hline
\end{tabular}

C: Code, 33-1: MAP minced meat, 72-1: MAP minced meat, 60-1: MAP cubed meat, 1E: E. coli O157, 2E: E. coli O157:H7, ST: Sulphamethoxazole- Trimethoprim $(25 \mu \mathrm{g})$, AM10: Ampicillin $(10 \mu \mathrm{g})$, AM30: Amoxicillin $(30 \mu \mathrm{g})$, CE30: Cephalothin $(30 \mu \mathrm{g})$, CH30: Chloramphenicol (30 $\mu \mathrm{g})$, TE30: Tetracycline (30 $\mu \mathrm{g})$, OX10: Oxfloxacin $(10 \mu \mathrm{g})$, CI10: Ciprofloxacin $(10 \mu \mathrm{g})$, ST10: Streptomycin $(10 \mu \mathrm{g})$, GE10: Gentamycin $(10 \mu \mathrm{g})$ 
All E. coli O157: H7 isolates tested in this study were found sensitive to tetracycline in parallel to 3 isolates of ewe's milk, fresh sausage and pig intestines obtained in the study carried out by Dontorou et al. (2004), in Greece. In another study, it was reported that E. coli O157: H7 isolates isolated from cattle were moderately resistant to ampicillin, sulfamethoxazole and cefoxitin, at the rates of $63.6 \%, 63.6 \%$ and $9.1 \%$, respectively, with the disc diffusion method (Goncuoglu et al., 2010).

$\mathrm{N}_{2}$ and $\mathrm{CO}_{2}$ are the two most frequently used gases in MAP technology, and the latter is liable for actual bacteriostatic effect. $\mathrm{O}_{2}$ helps to conserve the red colour of fresh meat by delaying the formation of metmyoglobin that gives the meat brown color (Farber 1991). Uyttendaele et al. (2001), reported that there was a reduction of $0.93 \log \mathrm{CFU} / \mathrm{g}$ at the level of $E$.coli $\mathrm{O} 157$ : $\mathrm{H} 7$ as a result of storing the packaged beef meat slices in the atmosphere containing $40 \% \mathrm{CO}_{2}$ at $4^{\circ} \mathrm{C}$ for one week. In the study carried out by Nissen et al. (2000), it was seen that the storage of minced meat in the environments containing $30 \%$ and $60 \% \mathrm{CO}_{2}$ at $10^{\circ} \mathrm{C}$ was not affected by $\mathrm{CO}_{2}$ concentration and the development of $E$. coli O157: $\mathrm{H} 7$ was nearly completely inhibited.

Barrera et al. (2007), have reported that $100 \% \mathrm{CO}_{2}$ and $35 \% \mathrm{CO}_{2}-35 \% \mathrm{O}_{2}$ and $30 \% \mathrm{~N}_{2}$ gas mixtures ensure inhibition on E. coli O157: $\mathrm{H} 7$ at the levels of $0.8 \mathrm{log}$ $\mathrm{CFU} / \mathrm{g}$ and $0.45 \mathrm{log} \mathrm{CFU} / \mathrm{g}$, respectively, but there is no full eradication. Ramamoorthi et al. (2009), reported that the inhibition of the gas mixtures used in MAP packaged meat products hardly became $1 \log$ on the $28^{\text {th }}$ day, and MAP packaging did not ensure full inhibition on $E$. coli O157: $\mathrm{H} 7$ of aerobic character.

\section{Conclusions}

Since there are no sufficient studies on the effect of the gases used in MAP technology which explains the development and survival of the pathogenic bacteria in meat products, this study was planned in order to examine the inhibition effect of MAP application. According to the results obtained from this research, it has been determined that there are pathogenic $E$. coli factors that may constitute a very serious danger in terms of human health in MAP packaged meat samples. It is considered that performing both the preparation and conservation processes of MAP packaged meat samples in accordance with hygienic processes is very important in terms of preventing the development of the infection due to the fact that $E$. coli O157: H7 may lead to extremely important infections in terms of human health, such as hemorrhagic colitis or haemolytic uremic syndrome, even at quite low titres ( $<10$ cells).

\section{References}

Abdul-Raouf UM, Ammar MS, Beuchat LR. 1996. Isolation of Escherichia coli O157: H7 from some Egyptian foods, International Journal of Food Microbiology, 29: 423-26.

Alişarlı M, Akman HN. 2004. Perakende satılan kıymaların Escherichia coli $\mathrm{O} 157$ yönünden incelenmesi, Yüzüncü Y1l Üniversitesi Veteriner Fakültesi Dergisi, 15: 65-69.
Barrera O, Rodríguez-Calleja JM, Santos JA, Otero A, GarcíaLópez ML. 2007. Effect of different storage conditions on $E$. coli $\mathrm{O} 157: \mathrm{H} 7$ and the indigenous bacterial microflora on lamb meat, International Journal of Food Microbiology, 115: 244-51.

Cagney C, Crowley H, Duffy G, Sheridan JJ, O'brien S, Carney E, Anderson W, McDowell DA, Blair IS, Bishop RH. 2004. Prevalence and numbers of Escherichia coli O157: H7 in minced beef and beef burgers from butcher shops and supermarkets in the Republic of Ireland, Food Microbiology, 21: 203-12.

Cooksey K. 2014. Modified Atmosphere Packaging of Meat, Poultry and Fish, Innovations in Food Packaging, 19: 47593.

Çadırcı Ö, Sırıken B, Inat G, Kevenk TO. 2010. The prevalence of Escherichia coli $\mathrm{O} 157$ and O157: $\mathrm{H} 7$ in ground beef and raw meatball by immunomagnetic separation and the detection of virulence genes using multiplex PCR, Meat Science, 84: 553-56.

Dontorou A, Papadopoulou C, Filioussis G, Apostolou I, Economou V, Kansouzidou A, Levidiotou S. 2004. Isolation of a rare Escherichia coli O157: H7 strain from farm animals in Greece, Comparative Immunology, Microbiology and Infectious Diseases, 27: 201-07.

Doyle MP, Schoeni JL. 1987. Isolation of Escherichia coli O157: H7 from retail fresh meats and poultry, Applied and Environmental Microbiology, 53: 2394-96.

Eklund M. 2005. Enterohemorrhagic Escherichia coli (EHEC) findings from humans in Finland (National Public Health Institute). Available from: http://www.julkari.fi/bitstream/handle/10024/78495/2005a2 3.pdf [15.06.2017]

Ertas N, Gonulalan Z, Yildirim Y, Karadal F, Abay S, Al S. 2013. Detection of Escherichia coli O157: H7 using immunomagnetic separation and MPCR in Turkish foods of animal origin, Letters in Applied Microbiology, 57: 373-79.

Fantelli K, Stephan R. 2001. Prevalence and characteristics of shigatoxin-producing Escherichia coli and Listeria monocytogenes strains isolated from minced meat in Switzerland, International Journal of Food Microbiology, 70: 63-69.

Farber JM. 1991. Microbiological aspects of modifiedatmosphere packaging technology-a review, Journal of Food Protection, 54: 58-70.

Fratamico P, Lori M, Bagi K, Pepe T. 2000. A multiplex polymerase chain reaction assay for rapid detection and identification of Escherichia coli O157: H7 in foods and bovine feces, Journal of Food Protection, 63: 1032-37.

Goncuoglu M, Bilir Ormanci FS, Ayaz ND, Erol I. 2010. Antibiotic resistance of Escherichia coli O157: H7 isolated from cattle and sheep, Annals of Microbiology, 60: 489-94.

Guyon R, Dorey F, Malas JP, Grimont F, Foret J, Rouviere B, Collobert JF. 2001. Superficial contamination of bovine carcasses by Escherichia coli O157: $\mathrm{H} 7$ in a slaughterhouse in Normandy (France), Meat Science, 58: 329-31.

Hussein HS, Sakuma T. 2005. Invited review: prevalence of Shiga toxin-producing Escherichia coli in dairy cattle and their products, Journal of Dairy Science, 88: 450-65.

Keleş A, Uçar G, Güner A. 2006. İnegöl köfte ve Hamburgerde E. coli O157: H7 varlığının araştırılması, Vet Bil Derg, 22: 51-57.

Law D. 2000. Virulence factors of Escherichia coli $\mathrm{O} 157$ and other Shiga toxin-producing E. coli, Journal of Applied Microbiology, 88: 729-45.

Maurer JJ, Denise S, Patricia P, Susan S, Lance B, Margie DL. 1999. Development of primers to O-antigen biosynthesis genes for specific detection of Escherichia coli $\mathrm{O} 157$ by PCR, Applied and Environmental Microbiology, 65: 295460. 
Meng J Zhao S, Zhao T, Doyle MP. 1995. Molecular characterisation of Escherichia coli $\mathrm{O} 157$ : $\mathrm{H} 7$ isolates by pulsed-field gel electrophoresis and plasmid DNA analysis, Journal of Medical Microbiology, 42: 258-63.

Nissen H Alvseike O, Bredholt S, Holck A, Nesbakken T. 2000. Comparison between the growth of Yersinia enterocolitica, Listeria monocytogenes, Escherichia coli O157: $\mathrm{H} 7$ and Salmonella spp. in ground beef packed by three commercially used packaging techniques, International Journal of Food Microbiology, 59: 211-20.

Ramamoorthi L, Toshkov S, Brewer MS. 2009. Effects of carbon monoxide-modified atmosphere packaging and irradiation on E. coli $\mathrm{K} 12$ survival and raw beef quality, Meat Science, 83: 358-65.

Sarimehmetoglu B, Kuplulu O, Kaymaz S. 1998. Isolation of Escherichia coli O157: $\mathrm{H} 7$ in hamburger and inegol meat balls, Ankara Univ Vet Fac J, 45: 221-27.

Schroeder CM, Zhao C, DebRoy C, Torcolini J, Zhao S, White DG, Wagner DD, McDermott PF, Walker RD, Meng J. 2002. Antimicrobial resistance of Escherichia coli O157 isolated from humans, cattle, swine, and food, Applied and Environmental Microbiology, 68: 576-81.

Temelli S, Eyigör AG, Anar Ş. 2012. Prevalence of Escherichia coli $\mathrm{O} 157$ in red meat and meat products determined by VIDAS ECPT and LightCycler PCR, Turkish Journal of Veterinary and Animal Sciences, 36: 305-10.
Uyttendaele M, Jozwik E, Tutenel A, Zutter LD, Uradzinski J, Pierard D, Debevere J. 2001. Effect of acid resistance of Escherichia coli O157: H7 on efficacy of buffered lactic acid to decontaminate chilled beef tissue and effect of modified atmosphere packaging on survival of Escherichia coli O157: H7 on red meat, Journal of Food Protection ${ }^{\circledR}$, 64: 1661-66.

Varela-Hernández JJ, Cabrera-Diaz E, Cardona-López MA, Ibarra-Velázquez LM, Rangel-Villalobos H, Castillo A, Torres-Vitela MR, Ramírez-Álvarez A. 2007. Isolation and characterization of Shiga toxin-producing Escherichia coli O157: $\mathrm{H} 7$ and non-O157 from beef carcasses at a slaughter plant in Mexico, International Journal of Food Microbiology, 113: 237-41.

Wayne PA. 2007. Clinical and laboratory standards institute, Performance Standards for Antimicrobial Susceptibility Testing, 17.

Willshaw GA, Thirlwell J, Jones AP, Parry S, Salmon RL, Hickey M. 1994. Vero cytotoxin-producing Escherichia coli O157 in beefburgers linked to an outbreak of diarrhoea, haemorrhagic colitis and haemolytic uraemic syndrome in Britain, Letters in Applied Microbiology, 19: 304-07.

Zhao S, White DG, Ge B, Ayers S, Friedman S, English L, Wagner D, Gaines S, Meng J. 2001. Identification and characterization of integron-mediated antibiotic resistance among Shiga toxin-producing Escherichia coli isolates, Applied and Environmental Microbiology, 67: 1558-64. 